\title{
Value, satisfaction and loyalty in volunteerism. Application to a religious megaevent
}

\author{
Elena Floristán Imízcoz, David Servera-Francés and Francisco Arteaga Moreno \\ Universidad Católica de Valencia San Vicente Mártir \\ Teresa Fayos Gardó and Martina G. Gallarza Granizo \\ Universitat de València
}

\begin{abstract}
This paper presents a study of the volunteer as an essential agent in the success of any event, and offers recommendations for improving management of megaevents. To achieve this goal we propose a structural model that analyses the multidimensionality of the value concept as antecedent of perceived value, satisfaction and loyalty. The study sample consists of volunteers who participated in the World Youth Day held in Madrid in 2011, obtaining a total number of 1427 cases. The results support all the hypotheses presented in the proposed model. Thus, it confirms that the multidimensionality of the value (spirituality, social value, play and efficiency) is an antecedent of perceived value while confirming the perceived value-satisfaction-loyalty chain. The most important background is play which shows that volunteering is better understood as entertainment, not as a job.
\end{abstract}

Keywords: Event, mega event, volunteerism, value, perceived value, satisfaction, loyalty.

JEL codes: J28, M54, M12, Z12.

\section{Introduction}

Using events as acts with a limited duration that empower attributes of a destination like knowledge, image and notoriety is an increasing phenomenon with numerous associated benefits (Hall, 1992; Lee and Taylor, 2005; Laws, 1995; Monga, 2006). Aligned with this strategic interest, the events management literature repeatedly underlines how difficult it is to coordinate the various stakeholders

\footnotetext{
*Corresponding author. Email: teresa.fayos@uv.es
}

ISSN 0212-1867 / e-ISSN 1989-3558

(C) ESIC Editorial, ESIC Business \& Marketing School

DOI: $10.7200 /$ esicm.146.0443.3i

http://www.esic.edu/esicmarket 
(Shone and Parry, 2004; Goldbaltt, 2001. This difficulty is an addition to the usually mentioned need in tourism of combining different groups of interest (Lee et al., 2010). This is made worse in the case of events because the existing conditioning of a strong time limitation.

Volunteers are one group of stakeholders, with a particular role in big events, because they are needed in large numbers to help with the event. Volunteers are a highly involved public with very specific characteristics (a high level of involvement with a possible lack of professionalism) that distinguish them from a labour force (Gallarza et al., 2009; Kemp, 2002).

Nevertheless, not every big event is the same, thereby conditioning volunteer profile, motivation and satisfaction even further. This study focuses on a religious event where volunteers seem to have higher altruist motivations (Gallarza et al., 2009; Gallarza et al., 2010) and greater involvement than in other events. Events in tourism is a rising line in tourism research and we predict a very fruitful future for religious tourism.

The main objective of this study is to examine volunteers' evaluation of their experience of the event. The study applies multidimensional scaling (Gallarza et al. $2009 ; 2010)$ to classic consumer behaviour variables, such as perceived value, satisfaction and loyalty as behavioural intention on a mass religious event held in August 2011 in the city of Madrid (World Youth Conference 2012)

The present paper is intended to contribute to the line of investigation into volunteers' experience at events, by studying a less known and less studied religious event. To achieve this goal, this paper is structured as follows: Below there is a review of terms like religious tourism, event typology and volunteering. Followed by a study of volunteers' assessments of their experience at events with the proposed model. Section 4 describes the empirical study, its objectives and methodology. Section 5 presents and analyses the results and, finally, Section 6 discusses the conclusions and recommendations for managing volunteers, the limitations of the study and future lines of investigation.

\section{Literature review: volunteering and events}

\subsection{Religious tourism and events}

The most common form of religious tourism: pilgrimage is acknowledged as one of the oldest types of tourism (Jacobsy and Smith, 1992), and has generated plenty of literature in this field (Raj and Morpeth, 2007; Timothy and Olsen, 2006; Sharpley and Jebson, 2011). Nevertheless, it is curious to observe that in the research of events in tourism, religious events have been little studied in comparison to sports, cultural or other megaevents. This fact can be explained because not even its conceptual delimitation or its categorisation in different typologies is unanimous in literature. So, such events can be considered both religious and/or cultural events (Ritchie, 1984), even though they have special features (Gallarza et al., 2010). Aca- 
demic researchers are therefore interested in the conceptual definition of religious events. The economic impact of religious tourism is also an area of interest (Vuconic, 2002) particularly from the managerial point of view.

\subsection{Categorisation of the religious event in events typologies}

As Brown and James (2004) point out, there are as many definitions of event as there are authors, in addition to the terminology regarding "special event", "megaevent" and "Hallmark event". The special event concept can be defined as "unique, infrequent events that take place outside normal activities. For consumers they are an amusement opportunity, a social or cultural experience that goes beyond their daily experience" (Getz, 2000). Goldblatt (1977) also specifies they are unique and occasional, a unique moment in the time celebrated with a ritual that satisfies a need. Allent et al. (2002) describe special events as celebrations, presentations or performances with a specific ritual created because of a special occasion and with the objective of obtaining specific social, cultural or corporative goals.

A Hallmark event adds to the special event term the capacity to create image and notoriety; thus Getz (2000) considers that "some events have acquired a level of remembrance and reputation that the images of the event and of the community have achieved to be inseparable". "Hallmark event" is translated in Jafari (2000) as "emblematic event", very closely aligned to Graham et al.'s (1995) proposal, that such events "mark a historical highlight".

As regards megaevents, theprefix "mega"means very large in Greek and a million in the metric system, so megaevents are events with a great impact or attraction "that bring an extraordinary level of tourists, media coverage, prestige or economic impact for the host community" (Getz, 2000). One of the most complete definitions is the one Donald Getz provided at a conference at the Swedish Institute for Regional Research in 1997: events planned with a limited duration that have an extraordinary impact in the area hosting them, in one or more of the following aspects: number of tourists, visitors expenses, notoriety that leads to greater familiarity and a better image, the development of infrastructures and related organizations that substantially increase the appeal and capacity of the destination" (Fayos-Sola, 1997)

Nevertheless, despite the numerous categorisation efforts (Ritchie, 1984; Getz, 1997; Maure, 2007), it is sometimes difficult to mark out and apply the megaevent notion because it is a relative concept that depends on two factors: the size of the host community and the type of impact expected. So, these events vary a lot in relation to their size and complexity: they can be simple and small, like a village carnival, or much larger and more complex and international, like the Olympic Games (Shone and Parry, 2004). In order to understand this complexity, different authors have provided typologies and many of them have developed classifications related to their diversity, sector, or even market (Ritchie, 1984; Getz, 1997; Goldblatt, 1997; Watt, 1998; Bowdin et al., 2001; Shone and Parry, 2004, Van Der Wagen, 2006; Maure, 2007). 
Ritchie's classification (1984) clearly collects the field of study of this paper in that it considers a group named Religious and Cultural Events. These events are described as non-commercial events but make an important contribution to tourism in specific regions. According to this author, its main objective is perhaps not to promote tourism (for instance, a Royal Coronation) but they attract a mass of visitors. Examples of the importance of some religious events are Hagg at the Meca (Saudi Arabia), a sacred annual pilgrimage for Muslims, attended each year by approximately 3.4 million people. Also, the Pope's visits to Catholics: the literaturereports John Paul II's visits to Ireland and the USA, where masses were held for more than one million people in Dublin, New York and Boston (Tum et el., 2009), and Benedict XVI's visit to Valencia (Gallarza et al., 2009 and 2010). Few categories of events are able to generate crowds like these, but there has been scanty academic interest, which we attempt to remedy with this empirical work.

\subsection{Volunteers as specific stakeholders in a megaevent}

One common aspect in every type of event is human resources administration, which is specifically characterised in megaevents by the complexity of dealing with different agents in a very limited time and space (Tum et al., 2009; Getz, 2005; Getz and Wicks, 1994; Bowdin et al., 2001). From amongst all the agents that take part in these events (workers, volunteers, managers and executives), volunteers are becoming the largest group (Goeldner et al., 2000; Kemp, 2002; Gallarza et al., 2009). As Getz (1991) notes, volunteer participation in an event is absolutely crucial for success.

The origin of this kind of volunteerism can be found in the traditional habit of organisers of sports or cultural events of involving residents in the organisation as a way of citizenship participation, which has often been multitudinous (Tosum, 1999 and 2006). Nevertheless, what originated in residents' good will is nowadays a need. There is currently increasing dependence on volunteers to make events economically and functionally viable (Chalip, 2000; Green and Chalip, 1998). This approach represents a big challenge for managers. However, De Cuskelly et al. (2004) emphasise that organisers usually consider volunteers as a free workforce and they do not consider improving their management of volunteers.

Many authors have noted that difficulties in managing volunteers are different to those related to employees. Vidal and Villa (2007) consider the following challenges in managing volunteerism: creating a managing model that is useful not only for employees but also for volunteers; organisations' need to adapt to new profiles of volunteerism; incorporating people from the business world into nonprofit organisations and, lastly, consolidating teams with a precarious economic situation in nonprofit organisations. Volunteers and employees increasingly have to work together as a team, and as Pauline and Pauline (2009) indicate understanding the motivation and orientation of all the groups involved will make management of the event more effec- 
tive. Even more, Garner and Garner (2011) also underline the need to look after and improve the relationship between employees and volunteers.

Additionally, nowadays organisations that manage volunteers are dealing with the emergence of new trends in volunteerism that affect both recruitment and withdrawal. Firstly, volunteering rates have stabilised and are beginning to slow down and withdrawal rates are often very high (Cortes et al., 1998; Mota and Vidal, 2003; Vecina, 2001). Secondly, we have found that some organisations attempt to retain volunteers but their main objective is to turn permanent volunteers into donors (Garner and Garner, 2011).

All the above aspects from the academic ones related to the problems of conceptual and typological delimitation of eventsand professional aspects related to managerial practices, point to the relevance of megaevents management. It is also very relevant to study events volunteers as a group and their management, and their specific features in relation to other types of volunteers and also to a workforce.

\section{Evaluation of volunteerism experience in events}

The literature on volunteerism is very varied because it is approached from different disciplines and the sociological components of the phenomenon vary greatly between countries and cultures. Getz (1997) points out that although events volunteers are different from other types of volunteers, all of them share some common characteristics which are useful for improving the way they are managed. These characteristics include in particular: enthusiasm with the event, lack of experience and need to practice, and for a lot of them, a search for fun and entertainment. Clary et al (1996), however, consider that there may be different motivations among volunteers in different contexts and areas in the same organization.

It is also necessary to consider that volunteer behaviour as a consumer is complex (Kim et al., 2010). Their motivations are very varied, as some previous studies report (e.g. Anderson and Moore, 1978; Cnaan and Goldberg-Glen, 1991; Farmer and Fedor, 2001; Knoke and Prensky, 1984; Miller, 1985). A religious event also has particularities related to volunteers, not only because of their large numbers but also because these volunteers show a higher altruistic motivation (Gallarza et al., 2009, 2010) and much more involvement with the event.

This study uses a conceptual model of volunteer experience based on the work by Gallarza et al. (2010) (See Figure 1). This model is based on the experiential and multidimensional nature of consumption value. The model considers the variable value as a central axis in the volunteer experience (Holbrook and Hirschman, 1982; Sheth et al., 1991; Babin et al., 1994; Holbrook, 1999). This perception of value has four precedents that reflect the dimensions of spirituality, social value, entertainment and efficiency in the volunteer experience.

Among the many values from the other-oriented dimension, spirituality is undoubtedly the most suitable value for the investigated experience. This first rela- 
tionship cannot be corroborated in literature because of the lack of previous studies. Nevertheless, recent works do show that religious practices positively influence the practice of volunteerism (Tao and Yeh, 2007). Therefore we posit:

H1: Increased spirituality directly and positively affects perceived value of the volunteer experience.

This other-oriented dimension also takes into account esteem and status in a positive dimension called social value (Holbrook, 1999). In addition to the theoretical support that social value provides in other value dimensionalities (Sheth et al., 1991; Sweeney and Soutar, 2001), Social Value must be measured in a volunteerism experience because it is closely connected with the desire for sociability (Pérez Álvarez, 2003). Other works also measure a positive relationship between Social Value and Perceived Value (Ledden et al., 2007; Gallarza and Gil, 2006b) and thus we posit:

H2: An increase in Social Value directly and positively affects the Perceived Value of the volunteer experience.

The variables Efficiency and Play were chosen for the self-oriented dimension because they are active values more closely linked to volunteerism than reactive values (Holbrook and Hirschman, 1982; Holbrook, 1999). Play corresponds to active hedonism, which is to be involved in a fun and enjoyable activity ("play" in English). This hedonic dimension is present in volunteerism (Monga, 2006). We expect Play to be related to Perceived Value as in other studies on tourism services (Lee et al., 2007; Sparks et al., 2008). Therefore we posit:

H3: An increase in Play directly and positively affects the Perceived Value of the volunteer experience.

The second self-oriented dimension is Efficiency, which in our study refers to time management in the organisation of the event and the volunteers' tasks. This relationship is confirmed in previous investigations on volunteerism in special events (Farrel et al., 1998), as well as in other investigations on value antecedents, as in Gallarza and Gil (2006a) or Ledden et al. (2007). So, we posit a last positive relationship between value antecedents and perceived value in the following hypothesis:

H4: An increase in Efficiency directly and positively affects the Perceived Value of the volunteer experience.

The negative aspect of value understood as trade-off (costs or sacrifices) was considered to involve only time and effort (Berry and Yadav, 1997). From among the more usually recognized costs in the consumption function (price, risk and time as detailed in Gallarza and Gil, 2006a), time and effort are the most suitable for vol- 
unteerism, where the volunteer has an opportunity cost but not a monetary cost or other consumption sacrifices like perceived risk.

H5: An increase in effort and time directly and negatively influences the Perceived Value of volunteer experience.

In the construction of our model, these five dimensions are considered to be direct antecedents ( 4 positive and 1 negative) of a first endogenous variable, Perceived Value.

Finally, the model introduces a chain of effects between global perception of value, a satisfaction evaluation and the likelihood of repetition and/or recommendation (H6 and H7), based on the means-end consumer behaviour approach. This is a very common chain in post purchase consumer behaviour studies (e.g. García and Rodriguez, 2011; Flores and García, 2012; Currás-Pérez and Sánchez-García, 2012), but less frequent in the scanty studies on satisfaction and loyalty in volunteers at religious megaevents. This lack of studies implies an important research opportunity, but complicates the conceptualisation and instrumentation of that chain. Marketing approaches satisfaction from a universal standpoint of satisfaction (Bowen and Clarcke, 2002), that is, considering it as a fulfillment response (Oliver, 1997).

Loyalty is more difficult to measure in volunteerism and even more so in such a specific area as a religious megaevent, because an individual is unlikely to have the opportunity to repeat this kind of event (Farrel et al., 1998). So, loyalty must be measured from the behavioural perspective (repetition or predisposition to repeat volunteerism), and from the attitudinal dimension (predisposition to recommendation).

Figure 1. Conceptual Model

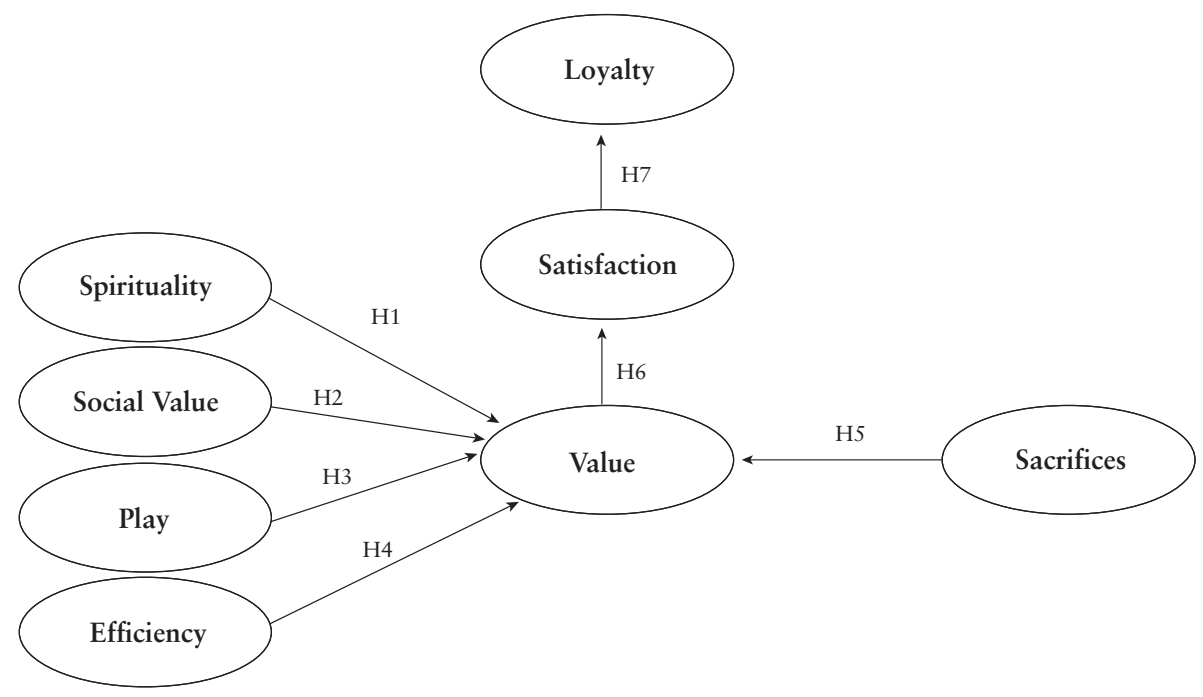




\section{Methodology}

\subsection{Description of the investigated event}

World Youth Congress (WYC) is a religious and cultural event that has been held every three years since 1985, and gathers young people from all over the world for one week. It is the most international and multitudinous event organized by the Catholic Church worldwide. According to the theoretical framework, because of its dimension and features, WYC would be a religious (cultural) event under Getz's classification (1997). It would be a religious and cultural event according to Ritchie (1984), a megaevent taking its size and importance into account (Getz, 2000), and a national event with foreign participation, non- governmental and assigned to the cultural sector, according to Maure's classification (2007).

According to Europa Press (14/08/2011), more than a million young people attended the WYC event in Madrid in August 2011. They came from 139 countries in the five continents. According to WYC Madrid 2011organization data, following other WYC percentages, one third approximately comes from the metropolitan area of the city in which the event takes place, another third comes from the organizer country and the rest are pilgrims from countries all over the world. The most numerous delegations are those from Italy, France, Poland, Germany and the USA. Attendees are in the 15-30 years old age range, with an average age of 23.9 years. $43 \%$ are women and $57 \%$ are men (many of them university students)

There were close to 22,400 volunteers at the WYC. Two clearly different profiles were identified: contributor and volunteer. Contributors are people that help with the event but are less involved with its management. Their involvement centers on the task assigned and they depend on the diocese parishes (they are known as diocesan volunteers). Volunteers are people that depend directly on the WYC Volunteer Organization and this organization assigns their tasks and plans their work.

Volunteers were recruited basically through mass media, social networks and parishes, and significant word-of-mouth among young people. The final selection was made through interviews and general and specific training sessions for all of them.

Volunteers(Europa Press 14/08/2011) were between 20-23 years old, and came from Spain (12,185), Poland (1,048), Italy (182), Mexico (91), France (81), Democratic Republic of Congo (67), Slovakia (53), Croatia (52), Brazil (48), Portugal (40) and the USA (37). Volunteers were responsible for a variety of tasks like assisting participants and reception at train stations, bus stations and airports; information to pilgrims at info points in the city; platforms and social networks management; collaboration in the Press Centre, translation and interpreting; in events logistics and order, accompanying authorities and group coordination. 


\subsection{Study aims}

The main objective of this study is to obtain a structural model that corroborates the scales in the literature on Value, Perceived Value, Satisfaction and Loyalty applied to volunteers' experience in a religious megaevent. As a secondary objective, the study attempts to confirm the multidimensionality of perceived value, applied to volunteers, while establishing the impact of each dimension on overall value. Finally, the study also aims to verify the value-satisfaction-loyalty chain of consequences.

The study uses a multidimensional value scale from the literature (Gallarza et al. 2009 and 2010), which was built on the basis of studies on the experiential and multidimensional nature of consumption values (e.g. Babin et al. 1994; Farrel et al., 1998; Holbrook, 1999; Strigas and Newton-Jackson, 2003; Monga, 2006) and applies it to the religious and multitudinous event that took place in Madrid in August 2011.

\subsection{Methodology}

The study uses two qualitative methodologies in the form of in-depth interviews combined with focus groups. Three in-depth interviews (50 to 60 minutes) were conducted with experts from the WYC Organization (the head of volunteer organization, the head of volunteer training, and the head of volunteer communication), and three role-playing sessions with different volunteer profiles. The selection of focus group participants is very important (Soler, 1997; Veal, 2006) Participants were selected on the basis of their affiliation as volunteers: belonging to a NGO or to a Catholic movement and participation in previous congresses, and social volunteers, university students and with no experience in congresses. Sampling was exploratory "ad libitum" sampling (Soler, 1997) because there were no preliminary categories (except that of being a WYC volunteer).

From the information obtained in the qualitative phase, a pre-test with ten volunteers was carried out, and with these results some aspects were modified. First, a 10-point Likert scale was adopted because it was considered easier to answer than the original one. Secondly, one answer option was added to the scale NA (Not Applicable). Then, the wording of several items was modified to make them clearer.

Finally, some questions were added on the identification of profiles, the type of work performed and its duration (to distinguish between permanent and occasional jobs), volunteer origin (diocesan or WYC web), as well as volunteer type (contributor or volunteer).

Permission to access the WYC volunteer database was obtained, but not the total database of 22,000 volunteers (that included diocesan volunteers). The questionnaire was sent by e-mail to 5,000 volunteers, including a text introducing the survey with its academic and non-profit aim, two weeks after the end of the event. 
A total of 1,427 valid questionnaires were collected: Table 1 shows the description of survey respondents. There is a high percentage of volunteers with previous experience $(57 \%)$. They are also highly educated, because more than $80 \%$ were university students or graduates. Most respondents are young women (living in Madrid (the host city).

Table 1. Sample description

\begin{tabular}{lrl}
\hline Sex & & \\
\hline Men & 635 & $44.50 \%$ \\
Women & 792 & $55.50 \%$ \\
\hline Origen & & \\
\hline Madrid & 720 & $50.46 \%$ \\
Other Places in Spain & 436 & $30.55 \%$ \\
Foreigners & 271 & $18.99 \%$ \\
\hline Education & & \\
\hline Primary & 17 & $1.19 \%$ \\
Secondary & 234 & $16.40 \%$ \\
College & 1176 & $82.41 \%$ \\
\hline Previous Experience & & \\
\hline Never & 616 & $43.17 \%$ \\
Once & 239 & $16.75 \%$ \\
Many & 572 & $40.08 \%$ \\
\hline Length of voluntary service & & \\
\hline Unknown & 43 & $3.01 \%$ \\
One Week & 1072 & $75.12 \%$ \\
Whole year & 285 & $19.97 \%$ \\
More than a year & & \\
\hline Type of registration & & \\
\hline Unknown & $3.89 \%$ \\
Individual & 391 & $21.09 \%$ \\
\hline In group & 439 & $30.76 \%$ \\
\hline Age & 949 & $66.50 \%$ \\
\hline Less than 20 & & \\
20 to 24 & 1427 & $3.64 \%$ \\
30 to 34 & 185 & $12.96 \%$ \\
35 to 39 & $7.36 \%$ \\
45 to 49 & $3.43 \%$ \\
More than 50 & & \\
\hline & & \\
\hline
\end{tabular}




\section{Results Analysis}

\subsection{Scales validation}

The following analysis was run to validate the proposed scales (see Tables 2, 3 and 4): Cronbach's alpha coefficient, average variance extracted (AVE), correlations between constructs and correlations of the indicators with their respective construct (loadings) and with the other constructs (cross loadings). These analyses are done to assure scale reliability, discriminant validity and convergent validity.

Table 2. Scales Depuration

\begin{tabular}{lcc}
\hline & alpha & $\begin{array}{c}\text { alpha if } \\
\text { item elim. }\end{array}$ \\
\hline Sp1 & 0.869 & 0.810 \\
Sp2 & & 0.809 \\
Sp3 & & 0.828 \\
\hline SV1 & 0.829 & 0.815 \\
SV2 & & 0.801 \\
SV3 & & 0.817 \\
SV4 & & 0.813 \\
SV5 & & 0.816 \\
SV6 & & 0.813 \\
SV7 & & 0.812 \\
SV8 & & 0.825 \\
SV9 & & 0.794 \\
\hline Play1 & 0.836 & 0.810 \\
Play2 & & 0.824 \\
Play3 & & 0.795 \\
Play4 & & 0.781 \\
Play5 & & 0.816 \\
Play6 & & 0.825 \\
\hline
\end{tabular}

\begin{tabular}{lcc}
\hline & alpha & $\begin{array}{c}\text { alpha if } \\
\text { item elim. }\end{array}$ \\
\hline Effi4 & 0.898 & 0.876 \\
Effi5 & & 0.858 \\
Effi6 & & 0.839 \\
Effi7 & & 0.897 \\
\hline Sacr1 & 0.870 & 0.817 \\
Sacr2 & & 0.810 \\
Sacr4 & & 0.824 \\
\hline Value1 & 0.898 & na \\
Value2 & & na \\
\hline Sat1 & 0.931 & $\mathrm{np}$ \\
Sat2 & & $\mathrm{np}$ \\
\hline Loy1 & 0.857 & 0.818 \\
Loy2 & & 0.748 \\
Loy3 & & 0.830 \\
\hline
\end{tabular}

Table 3. Inter-constructs correlations: consistence and reliability test

\begin{tabular}{|c|c|c|c|c|c|c|c|c|c|c|c|}
\hline & alpha & CR & & $\mathrm{Sp}$ & SV & Play & Effi & Sacr & Value & Sat & Loy \\
\hline Spirituality & 0,869 & 0,920 & Spirituality & 0,890 & & & & & & & \\
\hline Social Value & 0,829 & 0,868 & Social & 0,489 & 0,653 & & & & & & \\
\hline Play & 0,836 & 0,880 & Play & 0,48 & 0,763 & 0,743 & & & & & \\
\hline Efficiency & 0,898 & 0,928 & Efficiency & 0,353 & 0,498 & 0,552 & 0,874 & & & & \\
\hline Sacrifice & 0,870 & 0,920 & Sacrifice & 0,263 & 0,172 & 0,144 & 0,107 & 0,890 & & & \\
\hline Value & 0,898 & 0,951 & Value & 0,475 & 0,641 & 0,742 & 0,476 & 0,196 & 0,953 & & \\
\hline Satisfacti & 0,931 & 0,967 & Satisfactio & 0,473 & 0,579 & 0,652 & 0,419 & 0,172 & 0,761 & 0,967 & \\
\hline Loyalty & 0,857 & 0,912 & Loyalty & 0,412 & 0,588 & 0,681 & 0,469 & 0,088 & 0,734 & 0,711 & 0,88 \\
\hline
\end{tabular}


We accept the reliability of the eight scales because in all cases Cronbach's alpha is greater than 0.7 (see Table 2), the commonly accepted threshold (Nunnally, 1979). To reach these levels the scales have been purified by removing the items that reduced Cronbach's alpha. We removed three items of Spirituality (Sp4, Sp5 and Sp6), three of Efficiency (Effi1, Effi2 and Effi3), one of Sacrifice (Sacr3) and one of Satisfaction (Sat3).

Table 3 shows that Cronbach's alpha coefficients for all the constructs are sufficiently high, surpassing the 0.7 threshold (Nunnally, 1979) in all cases, with a minimum of 0.829 for Social Value. Composite reliability (CR in Table 3), which is a more accurate measure that does not assume equal item weight (tau equivalency), is even higher, for all constructs with values above 0.86. Table 3 also shows the AVE and correlations between pairs of constructs. Comparison of the square root of AVE (diagonal elements in Table 3), with correlations between constructs (off-diagonal elements in Table 3, which summarizes the association between different constructs) shows that each construct is more related to its items that with the other constructs. An exception is Play that correlates more highly with Social Value. The explanation for this must be sought in the affective nature of both constructs, probably related with the great importance of the affective dimension of the experience for volunteers. All constructs have an AVE value exceeding the recommended threshold of 0.50 (Fornell and Larcker, 1981; Chin, 1998).

Discriminant validity has been ensured by Sweeney and Soutar's (2001) first criterion: validity exists when correlations between constructs are significantly less than 1 , as in our case (Table 3). The highest correlations are between the dimensions of Social Value and Play, and between the three endogenous variables: Value, Satisfaction and Loyalty.

Table 4 shows the correlations of each indicator with its construct (loadings) and other constructs (cross loadings), which helps to confirm the convergent validity of the scales. Although there are some cross loadings, all indicators load more on their own construct than on other constructs and all constructs share more variance with their indicators than with other constructs. 
Table 4. Item to scale correlations

\begin{tabular}{|c|c|c|c|c|c|c|c|c|}
\hline & $S p$ & SV & Play & Effi & Sacr & Value & Sat & Loy \\
\hline Sp1 & 0.890 & 0.410 & 0.404 & 0.305 & 0.236 & 0.411 & 0.425 & 0.351 \\
\hline Sp2 & 0.897 & 0.481 & 0.479 & 0.315 & 0.257 & 0.435 & 0.424 & 0.389 \\
\hline Sp3 & 0.884 & 0.414 & 0.402 & 0.321 & 0.207 & 0.422 & 0.415 & 0.360 \\
\hline SV1 & 0.218 & 0.628 & 0.448 & 0.253 & 0.124 & 0.370 & 0.312 & 0.351 \\
\hline SV2 & 0.411 & 0.751 & 0.583 & 0.367 & 0.155 & 0.529 & 0.460 & 0.470 \\
\hline SV3 & 0.267 & 0.572 & 0.403 & 0.268 & 0.198 & 0.306 & 0.284 & 0.275 \\
\hline SV4 & 0.343 & 0.613 & 0.478 & 0.316 & 0.186 & 0.380 & 0.369 & 0.350 \\
\hline SV5 & 0.314 & 0.636 & 0.491 & 0.369 & 0.004 & 0.433 & 0.406 & 0.416 \\
\hline SV6 & 0.307 & 0.658 & 0.533 & 0.394 & 0.062 & 0.431 & 0.368 & 0.399 \\
\hline SV7 & 0.345 & 0.652 & 0.509 & 0.325 & 0.092 & 0.403 & 0.389 & 0.386 \\
\hline SV8 & 0.216 & 0.525 & 0.352 & 0.224 & 0.108 & 0.299 & 0.281 & 0.248 \\
\hline SV9 & 0.398 & 0.797 & 0.624 & 0.375 & 0.117 & 0.536 & 0.473 & 0.484 \\
\hline Play1 & 0.461 & 0.567 & 0.747 & 0.357 & 0.183 & 0.583 & 0.538 & 0.498 \\
\hline Play2 & 0.290 & 0.453 & 0.680 & 0.380 & 0.090 & 0.503 & 0.446 & 0.460 \\
\hline Play3 & 0.312 & 0.596 & 0.795 & 0.451 & 0.045 & 0.576 & 0.495 & 0.573 \\
\hline Play 4 & 0.432 & 0.631 & 0.855 & 0.469 & 0.150 & 0.664 & 0.546 & 0.563 \\
\hline Play5 & 0.336 & 0.636 & 0.716 & 0.488 & 0.065 & 0.543 & 0.474 & 0.527 \\
\hline Play6 & 0.292 & 0.509 & 0.643 & 0.288 & 0.098 & 0.393 & 0.383 & 0.390 \\
\hline Effi4 & 0.269 & 0.361 & 0.415 & 0.845 & 0.078 & 0.347 & 0.311 & 0.357 \\
\hline Effi5 & 0.294 & 0.407 & 0.453 & 0.885 & 0.102 & 0.388 & 0.334 & 0.383 \\
\hline Effi6 & 0.300 & 0.434 & 0.489 & 0.917 & 0.070 & 0.414 & 0.347 & 0.412 \\
\hline Effi7 & 0.354 & 0.513 & 0.547 & 0.849 & 0.117 & 0.488 & 0.447 & 0.467 \\
\hline Sacr1 & 0.238 & 0.159 & 0.147 & 0.107 & 0.894 & 0.175 & 0.160 & 0.098 \\
\hline Sacr2 & 0.258 & 0.177 & 0.139 & 0.092 & 0.912 & 0.200 & 0.173 & 0.081 \\
\hline Sacr4 & 0.197 & 0.112 & 0.088 & 0.086 & 0.863 & 0.139 & 0.115 & 0.050 \\
\hline Value1 & 0.440 & 0.598 & 0.696 & 0.445 & 0.167 & 0.951 & 0.716 & 0.690 \\
\hline Value2 & 0.465 & 0.624 & 0.718 & 0.461 & 0.206 & 0.954 & 0.733 & 0.708 \\
\hline Sat1 & 0.461 & 0.557 & 0.627 & 0.394 & 0.167 & 0.736 & 0.967 & 0.683 \\
\hline Sat2 & 0.455 & 0.563 & 0.634 & 0.416 & 0.164 & 0.736 & 0.967 & 0.691 \\
\hline Loy1 & 0.266 & 0.455 & 0.514 & 0.344 & 0.048 & 0.548 & 0.508 & 0.845 \\
\hline Loy2 & 0.413 & 0.571 & 0.672 & 0.443 & 0.083 & 0.678 & 0.624 & 0.907 \\
\hline Loy3 & 0.390 & 0.520 & 0.601 & 0.438 & 0.094 & 0.692 & 0.715 & 0.889 \\
\hline
\end{tabular}

\subsection{Analysis and results of the structural model}

Figure 2 shows the proposed model estimated by the PLS method. This study uses the algorithm MultiBlock Partial Least Squares Path Modeling (MBPLSPM), which provides better results than the classical PLS (factors with greater explanatory capability and coefficients with lower standard error) (Arteaga et al., 2010).

All coefficients are significant. The model explains $58.30 \%$ of the variance of Value, the $57.87 \%$ of the variance of Satisfaction, and $50.49 \%$ of the variance of Loyalty. 
Figure 2. The model, estimated

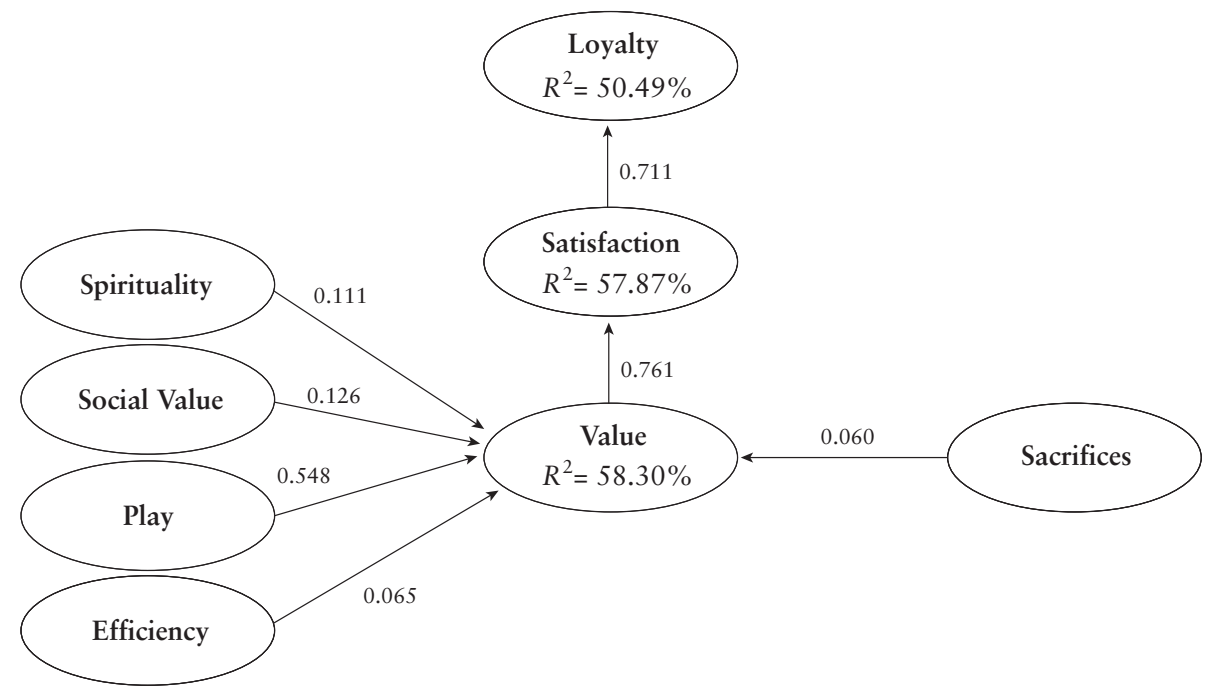

Results shown in Figure 2 support every hypothesis in the proposed model, confirming that value multidimensionality (spirituality, social value, play and efficiency) is an antecedent of perceived value and also confirming the value-satisfaction-loyalty chain. The most significant antecedent is Play $(0.548)$, showing that volunteerism is understood as entertainment and not as a job, in accordance with the most modern conceptualizations. In general, these results establish stronger links between the variables in the model, especially Sacrifices that in this case is significant.

Table 5 shows the estimated coefficients of the structural model with its corresponding confidence intervals. It also includes the corresponding $p$-value. The table shows that every coefficient is significant.

Table 5. Estimated Coefficients for the structural model and their Confidence Intervals

\begin{tabular}{lllllr}
\hline From & To & Coeff & \multicolumn{2}{c}{ CI $_{95 \%}$} & p-value \\
\hline Spir & Value & 0.111 & 0.063 & 0.161 & $<0.0001$ \\
SV & Value & 0.126 & 0.064 & 0.192 & 0.0001 \\
Play & Value & 0.548 & 0.480 & 0.616 & $<0.0001$ \\
Effi & Value & 0.065 & 0.024 & 0.107 & 0.0021 \\
Sacr & Value & 0.060 & 0.018 & 0.101 & 0.0056 \\
Value & Sat & 0.761 & 0.724 & 0.794 & $<0.0001$ \\
Sat & Loy & 0.711 & 0.672 & 0.745 & $<0.0001$ \\
\hline
\end{tabular}

Finally, Table 6 shows the explained variance percentage $\left(R^{2}\right)$, and the corresponding bootstrap confidence interval for every endogenous construct. The confi- 
dence interval limits have been estimated using bootstrap (Efrom and Tibshirani, 1993) on 1,000 samples with replacement from the original data set. Analysis of these percentages shows the value-satisfaction-loyalty chain robustness: more than $50 \%$ of satisfaction and loyalty variance is explained by their antecedents.

Table 6. Explained variance $\left(R^{2}\right)$ for each endogenous construct and confidence interval

\begin{tabular}{lcrr}
\hline & $\boldsymbol{R}^{2}$ & \multicolumn{2}{c}{$\mathbf{C I}_{95 \%}$} \\
\hline Value & $58.30 \%$ & $53.75 \%$ & $62.90 \%$ \\
Sat & $57.87 \%$ & $52.35 \%$ & $62.99 \%$ \\
Loy & $50.49 \%$ & $45.11 \%$ & $55.47 \%$ \\
\hline
\end{tabular}

\section{Conclusions}

This paper has categorically validated the structure and the model, confirming that Value variable multidimensionality (Spirituality, Social value, Play and Efficiency) is an antecedent of Perceived Value, and also confirms the value-satisfaction-loyalty chain.

The study also suggests other partial conclusions that ratify those obtained in previous studies. First, it confirms Perceived Value multidimensionality as a tradeoff between positive and negative variables. It also proves that perceived value is applicable to volunteerism. In our study volunteers perceive high social and personal value from this experience (Strigas and Newton-Jackson, 2003) implying a high level of satisfaction that becomes loyalty to the organization and to the experience of volunteerism itself. This loyalty is both behavioural (intention to repeat the experience) and attitudinal (willingness to recommend the experience to others). Thus, this study confirms the strength of the links chain suggested between Perceived Value, Satisfaction and Loyalty, this time in a little explored setting like volunteerism.

These findings have implications for volunteer management in events. Some of the great challenges in volunteer management that organizations face have emerged from the quantitative and qualitative analysis. Some of those challenges have already been discussed before in literature and others are closer to the idiosyncrasy of the studied event.

First of all, better understanding of the mechanisms that lead to volunteers' fidelity is a priority. Lack of knowledge on factors and processes that affect volunteerism (Dávila and Chacón, 2004) prevents organizations from making the best use of volunteers.

In fact, the most relevant second variable to build the perceived value of volunteerism also has a clear social component. Spirituality is also significant because of the event's religious characteristics. Efficiency is less significant, probably because of 
the altruistic nature of volunteerism. As the volunteers are not professional, they do not have high expectations of the organization's professionalism. However, organizations must not neglect this aspect, because the qualitative work shows an increasing demand for more professionalism in organizing volunteer work. Many volunteers found it frustrating not knowing what they were supposed to do at some moments or not having anything to do for a long period of time.

Organizational volunteerism structures must be improved. People who want to become volunteers are sometimes not well guided, and so they do not usually fit properly either in an organization or in an activity that allows them to satisfy their desire to volunteer. As a result, they ventually abandon volunteerism, which implies a loss of resources for the organization (Dávila and Chacón, 2005). Activities and types of volunteers should be segmented, developing theories for each segment to increase volunteer usefulness and reduce confusion (Wilson, 2000).

Future intentions have sometimes been undervalued as a behaviour of interest for the non-profit sector investigator (Hagedoorn et al., 1999; Rusbult et al., 1988; Withey and Cooper, 1989). Dissatisfaction among volunteers can cause them to behave in ways that do not favour the organization or the non-profit association (Hagedoorn et al., 1999)Thus the volunteer has a fundamental role as a stakeholder in the event.

The main limitation in this study is the process of sending questionnaires by email. The procedure is a fast, easy way of obtaining a large sample, but it is difficult to control respondent identity. If we had added new variables we might have been able to define a more complex model that would have given new interactions.

As regards new lines of investigation, it is undoubtedly interesting to retest the model with new samples to improve robustness. New relationships among the variables could be defined and a volunteer segmentation analysis could be run depending on social-demographic variables, for instance nationality. Finally, it would be very interesting to compare results for volunteers with other groups, for instance with employee results in order to analyse the differences between both kinds of work.

\section{References}

Allen, J., O’Toole, W., Mcdonnell, I. and Harris, R., 2002, Festival and special event management. $2^{\mathrm{a}}$ ed. Australia: Wiley.

Anderson, J.C. and Moore, L.F., 1978, “The motivation to volunteer”. Journal of Voluntary Action Research, Issue 7, pp. 120-129.

Arteaga, F., Gallarza, M. and Gil, I., 2010, “A New Multiblock PLS Based Method to Estimate Causal Models. Application to the Post-Consumption Behavior in Tourism". In V. Esposito Vinzi, W.W. Chin, J. Henseler and H. Wang (ed.), Handbook of Partial Least Square. Concepts Methods and Application in Marketing and Related Fields. Heidelberg. 
Babin, B.J., Darden, W.R. and Griffin, M., 1994, “Work and/or fun: measuring hedonic and utilitarian shopping value". Journal of Consumer Research, Issue 20, pp. 644-656.

Berry, L.D. and Yadav, M.S., 1997, "El papel del valor en la determinación del precio de los servicios”. Harvard Deusto Business Review, Vol. 78, pp. 26-37.

Bowdin, G., Mcdonnell, A.J. and O`Toole, W., 2001, Events Management. Oxford: Butterworth Heinemann, pp. 12-14.

Bowen, D. and Clarcke, J., 2002, "Reflections on tourist satisfaction research: Past, present and future". Journal of Vacation Marketing, Vol. 8, Issue 4, pp. 297-308.

Brown, S. and James, J., 2004, “Event design and management: ritual sacrifice?”. In Yeoman, Robertson, Ali-Knight, Drummond and McMahon-Beattie (eds.), Festival and events management: an international arts and culture perspective. Oxford: Elsevier, pp. 53-64.

Chalip, L., 2000, "Sydney 2000 volunteers and the organisation of the Olympic Games: Economic and formative aspects”. In Moragas, M., Moreno, A.B. and Puig, N. (eds.), Volunteers, Global Society and the Olympic Movement. International Olympic Committee, Lausanne, Switzerland, pp. 205-214.

Chin, W.W., 1998, “The Partial Least Squares Approach to Structural Equation Modeling”. In G.A. Marcoulides (ed.), Modern Methods for Business Research. Mahwah, Lawrence Erlbaum Associates.

Clary, E.G., Snyder, M. and Stukas, A.A., 1996, "Volunteers' motivations: Findings from a national survey". Nonprofit and Voluntary Sector Quarterly, Vol. 25, Issue 4, pp. 485-505.

Cnaan, R.H. and Godberg-Glen, R.S., 1991, "Measuring motivations to volunteers Human Services”. Journal of Applied Behavioural Science, Issue 27, pp. 269-284.

Cortes, L., Hernán, M.J. and López, O., 1998, Las organizaciones de voluntariado en España. Madrid: Plataforma para la Promoción del Voluntariado en España.

Currás-Pérez, R. and Sánchez-García, I., 2012, "Satisfaction and Loyalty to a Website: TheModerating Effect of Perceived Risk". Esic Market Economic and Business Journal, Vol. 141, pp. 209-234.

Cuskelly, G., Auld, C., Harrington, M. and Coleman, D., 2004, "Predicting the behavioural dependability of sport event volunteers". Event Management, Issue 9, pp. 73-89.

Dávila, M.C. and Chacón, F., 2004, “Factores psicosociales y tipo de voluntariado”. Psicothema, Vol. 16, Issue 4, pp. 639-645.

Dávila, M.C. and Chacón, F., 2005, "Diferencias entre voluntarios ecologistas y socioasistenciales en el perfil sociodemográfico”. Revista de Psicología Social Aplicada, Vol. 13, Issue 3.

Efrom, B. and Tibshirani, R., 1993, Introduction to the Bootstrap. New York: Chapman-Hall.

Farmer, S.M. and Fedor, D.B., 2001,"Changing the Focus on Volunteering: An Investigation of Volunteers' Multiple Contributions to a Charitable Organization”. Journal of Management, Issue 27, pp. 191-211. 
Farrel, J.M., Johnston, M.E. and Twynam, G.D.,1998, "Volunteer motivation, satisfaction, and management at an elite sporting competition". Journal of Sport Management, Vol. 12, pp. 288-300.

Fayos-Solá, E., 1997, “The Impact of mega events”. Annals of Tourism Research, Notes and Reports, Vol. 25, Issue 1, pp. 241-257.

Flores Zamora, J. and García Madariaga, J., 2012, "Identification and measurement of opinion leadership, satisfaction and loyalty in art services". Esic Market Economic and Business Journal, Vol. 43, Issue 2, May-August, 349-370.

Floristan, E., 2011, Voluntariado y megaeventos: análisis de la experiencia de consumo y perspectiva de gestión. Tesis Doctoral no publicada, Universidad Católica de Valencia.

Fornel, C. and Larcker, D.F., 1981, "Evaluating Structural Equation Models with unobservable Variables and Measurement Error”. Journal of Marketing Research, Vol. 18, pp. 39-50.

Gallarza, M,G. Servera, D., Arteaga, F. and Gil, I., 2010, "La dimensionalidad de valor en la experiencia de voluntario en un mega-evento turístico". Revista Europea de Dirección y Economía de la Empresa, Vol. 19, Issue 4, pp. 149-170.

Gallarza, M.G. and Gil, I., 2006a, "Desarrollo de una escala multidimensional para medir el valor percibido en una experiencia de servicio”. Revista española de investigación y marketing ESIC, Issue 18, pp. 35-60.

Gallarza, M.G. and Gil, I., 2006b, "Value dimensions, perceived value, satisfaction and royalty: an investigation of university students' travel behaviour". Tourism Management, Vol. 27, pp. 437-452.

Gallarza, M.G., Arteaga, F., Floristán, E. and Gil, I., 2009, “Consumer behavior in a religious event experience: An empirical assessment of value dimensionality among volunteers". International Journal of Culture, Tourism, \& Hospitality Research, Vol. 3, Issue 2, pp. 165-180.

García de los Salmones, M.M. and Rodríguez del Bosque, I., 2011, “Corporate social responsability and loyalty in services sector”. Esic Market Economic and Business Journal, Vol. 138, pp. 199-221.

Garner, J.T. and Garner, L.T., 2011, "Volunteering an Opinion: Organizational Voice and Volunteer Retention in Nonprofit Organizations". Nonprofit and Voluntary Sector Quarterly, Vol. 40, Issue 5, pp. 813-828.

Getz, D. and Wicks, B., 1994, "Professionalism and certification for festival and event practitioner: trends and issues". Festival Management and Event Tourism, Vol. 1, Issue 1, pp. 1-3.

Getz, D., 1991, Festivals, Special Events and Tourism. Nueva York: Van Nostrand Reinhold.

Getz, D., 1997, Event Management and Event Tourism. New York: Cognizant Communication Corporation.

Getz, D., 2000, “Festivals and special events: Life cycle and saturation issues”. In W. Garter, and D. Lime (eds.). Trends in outdoor recreation leisure and tourism. Wallingford, UK: CABI, pp. 175-185. 
Getz, D., 2005, Event management and event tourism. $2^{\mathrm{a}}$ ed. New York: Cognizant. Goeldner, R.C., Ritchie, J.R.B. and Mcintosh, W.R., 2000, Tourism. Principles, Practices, Philosophies. USA: Wiley.

Goldblatt, J.J., 1997, Special events: Best practices in modern event management. New York: Van Nostrand Reinhold.

Goldblatt, J.J., 2001, Special Events: The Art and Science of Modern Event Management. Chichester: Wiley.

Graham, S., Goldblatt, J.J, and Delby, I., 1995, The ultimate guide to Sport Event Management and Marketing. Chicago: Irwin.

Green, B.C. and Chalip, L., 1998, "Sport Volunteers: Research Agenda and Applications". Sport Marketing Quarterly, Vol. 7, Issue 2, pp. 14-23.

Hagedoorn, M., Van Yperen, N.W., Van DE Vliert, E. and Buunk, B.P., 1999, "Employees'reaction to problematic events: A circumplex structure of five categories of responses, and the role of job satisfaction". Journal of Organizational Behavior, Issue 20, pp. 309-321.

Hall, C., 1992, Hallmark Tourist Events: Impacts, Management and Plannings. Londres: Belhaven Press.

Holbrook, M.B. and Hirschman, E.C., 1982, “The experiential aspects of consumption: consumer fantasies, feelings and fun”, Journal of Consumer Research, Issue 9, pp.132-140.

Holbrook, M.B., 1999, Consumer value. A framework for analysis and research. London: Routledge.

Hunter, W.C., 2011, "Rukai indigenous tourism: Representations, cultural identity and Q method", Tourism Management, Vol. 32, Issue 2, pp. 335-348.

Jackowski, A. and Smith, V., 1992, "Polish pilgrim-tourists". Annals of Tourism Research, Issue 19, pp. 92-106.

Jafari, J., 2000, Enciclopedia del Turismo, Madrid: Editorial Síntesis.

Kemp, S., 2002, "The hidden workforce: volunteers' learning in the Olympics". Journal of European Industrial Training, Vol. 26, Issue 2-4, pp. 109-116.

Kim, M., Zhang, J.J. and Connaughton, D.P., 2010, "Comparison of Volunteer Motivations in Different Youth Sport Organizations”. European Sport Management Quarterly, Vol. 10, Issue 3, pp.343-365.

Knoke, D. and Prensky, P., 1984, "What relevance do organization theories have for volunteer associations?”. Social Science Quarterly, Issue 65, pp. 3-20.

Kotler, P., Cámara, D., Grande, I. and Cruz, I., 2000, Dirección de marketing, Madrid: Prentice Hall.

Laws, E., 1995, Tourism Destination Management. Issues Analysis and Policies. London: Routledge.

Ledden, L., Kalafatis, S. and Samoul, P., 2007, “The relationship between personal values and perceived value of education”. Journal of Business Research, Vol. 60, Issue 9, pp. 965-974.

Lee, C. and Taylor, T., 2005, "Critical reflections on the economic impact assessment of a mega-event: the case of 2002 FIFA World Cup". Tourism Management, Issue 26, pp.595-603. 
Lee, C.T., Yang, S.C. and Lo, H.Y., 2008, "Customer Satisfaction and Customer Characteristics in Festival Activity. A Case of 2008 Kenting Wind Chime Festival". International Journal of Culture, Tourism and Hospitality Research, Vol. 2, Issue 3, pp. 234-249.

Lee, T.J., Riley, M. and Hampton, M.P., 2010, "Conflict and Progress: Tourism Development in Korea". Annals of Tourism Research, Vol. 37, Issue 2, pp. 355-376.

Lo, A.S. and Lee, C.Y.S., 2011, "Motivations and perceived value of volunteer tourists from Hong Kong”. Tourism Management, Issue 32, pp. 326-334.

Lovelock, C. H., 1996, Services Marketing (3rd Edition). New Jersey, USA: Prentice Hall.

Maure Agüero, G., 2007, “Definiciones y tendencias del turismo de eventos”. Contribuciones a la Economía, 82. Retrieved from: http://www.eumed.net/ce/2007b/ gma.htm.

Miller, L.E., 1985, "Understanding the motivation of volunteers: An examination of personality differences and characteristics of volunteers' paid employment". Journal of Voluntary Action Research, Issue 14, pp. 112-122.

Monga, M., 2006, Measuring motivation to volunteer for special events. Event Management, Issue 10, pp. 47-61.

Monroe, K.B., 1992, Pricing. Making Profitable Decisions. New York: McGraw Hill.

Mota, R. and Vidal, F., 2003, Solidaridad y morfología de los voluntarios madrileños: informe de investigación. Madrid: Dirección General de Inmigración, Cooperación al Desarrollo y Voluntariado. Consejería de Servicios Sociales. Comunidad de Madrid.

Nunnally, J.C., 1979, Psychometric theory. New York, McGraw-Hill.

Oliver, R.L., 1997, Satisfaction. A Behavioural Perspective on the Consumer. McGraw- Hill. New York.

Parasuraman, A. and Grewal, D., 2000, “The impact of technology on the qualityvalue-loyalty chain: a research agenda". Journal of the Academy of Marketing Science, Vol. 28, Issue 1, pp. 168-174.

Park, H.Y., 2010, “Heritage Tourism: Emotional Journeys into Nationhood". Annals of Tourism Research, Vol. 37, Issue 1, pp. 116-135.

Pauline, G. and Pauline, J.S., 2009, "Volunteer motivation and demographic influences at a professional tennis event”. Team Performance Management, Vol. 15, Issue 3/4, pp. 172-184.

Pérez Álvarez, J.L., 2003, El referente grupal del voluntariado Plataforma para la promoción del voluntariado en España. Madrid.

Raj, R. and Morpeth, N., 2007, Religious Tourism and Pilgrimage Management, an International Perspective. Oxford: Cabi.

Ritchie, J.R.B., 1984, “Assessing the impact of hallmark events: Conceptual and research issues". Journal of Travel Research, Vol. 22, Issue 1, pp. 2-11. 
Rusbult, C.E., Farrell, D., Rogers, G. and Mainous, A.G.III., 1988, "Impact of exchange variables on exit, voice, loyalty, and neglect: An integrative model of responsiveness to declining job satisfaction". Academy of Management Journal, Issue 31, pp. 599-627.

Sharpleya, R. and Jepsona, D., 2011, “Rural tourism: A spiritual experience?". Annals of Tourism Research, Vol. 38, Issue 1, pp. 52-71.

Sheth, J.N., Newman, B.I. and Gross, B.L., 1991, "Why we buy what we buy: a theory of consumption values". Journal of Business Research, Issue 22, pp. 159-170.

Shone, A. and Parry, B., 2004, Succesful event management: a practical handbook ( $2^{\text {nd }}$ ed).

Soler, P., 1997, La investigación cualitativa en marketing y publicidad: el grupo de discusión y el análisis de datos. Barcelona: Ediciones Paidos Ibérica.

Sparks, B.; Butcher, K. and Bradley, G., 2008, "Dimensions and correlates of consumer value: an application of the timeshare industry". International Journal of Hospitality Management, Vol. 27, pp. 98-108.

Spencer, D.M., 2010, “Case Study. Facilitating public participation in tourism planning on American Indian reservations: A case study involving the Nominal Group Technique". Tourism Management, Issue 31, pp. 684-690.

Strigas, A. and Newton-Jackson, E., 2003, "Motivating volunteers to serve and succeed: Design and results of a pilot study that explores demographic and motivational factors in sport volunteerism”. International Sports Journal, Vol. 7, Issue 1, pp.11-123.

Sweeney, J. and Soutar, G., 2001, "Consumer perceived value: the development of a multiple item scale”. Journal of Retailing, Issue 77, pp. 203-207.

Tao, H.L. and Yeh, P., 2007, "Religion as an investment: comparing the contributions and volunteer frequency among Christians, Buddhists and Fol. Religionits”. Southern Economic Journal, Vol. 73, Issue 3, pp. 770-790.

Timothy, D. and Olsen, D., Eds., 2006, Tourism, religion and spiritual journeys. London, New York: Routledge.

Tosum, C., 1999, "Towards a typology of community participation in the tourism development process". International Journal of Tourism and Hospitality, Issue 10, pp. 113-134.

Tosum, C., 2006, "Expected nature of community participation in tourism development”. Tourism Management, Issue 27, pp. 493-504.

Tum, J., Norton, P. and Wright, J.W., 2009, Events Management . Series. Elsevier.

Van Der Wagen, L., 2006, Human resource management for events: Managing the event workforce. Oxford: Butterworth-Heinemann.

Veal, A.J., 2006, Research methods for leisure and tourism: a practical guide. 3rd. Ed. Pearson Education.

Vecina, M. L., 2001, Factores psicosociales que influyen en la permanencia del voluntariado. Universidad Complutense de Madrid. Tesis doctoral no publicada.

Vidal, P. and Villa, A., 2007, "Las personas en las organizaciones del Tercer Sector". Tercer sector, trabajo autónomo y responsabilidad corporativa, $3^{\mathrm{a}}$ Época, Issue 40, pp. 10-13. 
Watt, D., 1998, Event Management in Leisure and Tourism. Longman.

Wilson, J., 2000, "Volunteering”. Annual Review of Sociology, Vol. 26, Issue 1, pp. 215-240.

Withey, M.J. and COOPER, W.H., 1989, "Predicting exit, voice, loyalty, and neglect". Administrative Science Quarterly, Issue 34, pp. 521-539.

Yoon, Y. and Uysal, M., 2005, "An Examination of the Effects of Motivation and Satisfaction on Destination Loyalty: A Structural Model”. Tourism Management, Issue 26, pp. 45-56.

Zeithaml, V.A., and Bitner, M.J., 1996, Services Marketing. USA: McGraw Hill. 


\section{Notes on Contributors}

Name: Elena Floristán Imizcoz

Position: Directora del Área de Postgrado y Títulos Propios de la Universidad Católica de Valencia

School/Faculty: Facultad de Ciencias Económicas

University: Universidad Católica de Valencia

Address: c/Corona, 34. 46003 Valencia

Telephone: 963637412

Email: elena.floristan@ucv.es

Name: Teresa Fayos Gardó

Position: Profesora Contratada Doctor del Departamento de Comercialización e Investigación de Mercados

School/Faculty: Facultad de Economía

University: Universidad de Valencia

Address: Avda. Tarongers s/n, 46022. Valencia

Telephone: 961625379

Email: teresafayos@uv.es

Name: David Servera Francés

Position: Vicedecano

School/Faculty: Facultad de Ciencias Económicas

University: Universidad Católica de Valencia

Address: c/Corona, 34. 46003 Valencia

Telephone: 963637412

Email: david.servera@ucv.es

Name: Francisco Arteaga Moreno

Position: Director del Departamento de Contabilidad, Finanzas y Control de Gestión

School/Faculty: Facultad de Ciencias Económicas

University: Universidad Católica de Valencia

Address: c/Corona, 34. 46003 Valencia

Telephone: 963637412

Email: francisco.arteaga@ucv.es

Name: Martina G. Gallarza Granizo

Position: Profesora Contratada Doctor del Departamento de Comercialización e Investigación de Mercados

School/Faculty: Facultad de Economía

University: Universidad de Valencia

Address: Avda. Tarongers s/n, 46022. Valencia

Telephone: 961625380

Email: martina.gallarza@uv.es 
